\title{
Agronomic performance of soybean genotypes submitted to different population densities in the city of Uberlândia - MG
}

\author{
Desempenho agronômico de genótipos de soja submetida a diferentes \\ densidades populacionais no município de Uberlândia - MG
}

\section{Beliza Queiroz Vieira MACHADO'; Ana Paula Oliveira NOGUEIRA ${ }^{2}$; Gabriel Fernandes REZENDE; Fernanda Gabriela Teixeira COELHO ${ }^{4}$; Gessyca Ferreira GOMES ${ }^{5}$; Filipe Cardoso BERNARDES 6 ; Abadia dos Reis NASCIMENTO7; Raphael Lemes HAMAWAKI ${ }^{8}$}

${ }^{1}$ Autor para correspondência, Mestre em Agronomia, Universidade Federal de Uberlândia, Avenida Amazonas s/ no - Bloco 2E Sala 01 - Bairro Umuarama - Uberlândia/MG - CEP 38400-902 - Caixa Postal: 593. beliza_queiroz@hotmail.com.

${ }^{2}$ Professor, Universidade Federal de Uberlândia, anap812004@yahoo.com.br.

${ }^{3}$ Mestre em Agronomia, Universidade Federal de Uberlândia, gabriel.f.rezende@hotmail.com.

${ }^{4}$ Mestre em Agronomia Universidade Federal de Uberlândia, fernanda.gab.teixeira@gmail.com.

${ }^{5}$ Graduanda em Biotecnologia, Universidade Federal de Uberlândia, gessyca_fg@hotmail.com.

${ }^{6}$ Graduando em Agronomia, Universidade Federal de Uberlândia, filipicardoso78@hotmail.com.

${ }^{7}$ Professora, Universidade Federal do Goiás, abadiadosreis@ufg.br.

${ }^{8}$ Doutorando em Melhoramento de Plantas, Southern Illinois University Carbondale, raphael.hamawaki@yahoo.com.br.

Recebido em: 18-05-2017; Aceito em: 19-02-2018

\begin{abstract}
Sowing density is widely studied in the soybean crop in order to define the best plant population for each cultivar available on the market. The objective of this work was to evaluate the agronomic traits of three soybean genotypes (UFUS LVR, UFUS 7910, and UFUS 8301) in four population densities $\left(12 ; 14 ; 16 ; 18 \mathrm{pl} \mathrm{m}^{-1}\right.$ ), in Uberlândia-MG. The design was a randomized complete block with four replicates, with sowing performed on February 12, 2016. The following were evaluated: plant height at flowering (PHF) and maturity (PHM); number of branched nodes (NBN); lateral branch inclination (LBI); first pod insertion height (FPIH); number of pods per plant (NPP); number of seeds per pod (NSP); hundred-grain weight (HGW); and grain yield (kg ha-1). There were significant interactions between genotypes and densities for all characters, except for LBI and NSP. When increasing the sowing density from 14 to $18 \mathrm{pl} \mathrm{m}^{-1}$, cultivar UFUS 7910 showed a reduction in plant height at maturity, and strain UFUS LRV had the first pod insertion height increased. The hundred-grain weight was not altered for cultivars UFUS LRV and UFUS 7910 when increasing the density from 12 to $18 \mathrm{pl} \mathrm{m}^{-1}$. For the three genotypes, there was a reduction in grain yield when sown in a higher sowing density (density of $18 \mathrm{pl} \mathrm{m}^{-1}$ ). The densities of $16 \mathrm{pl} \mathrm{m}^{-1}$ and $12 \mathrm{pl} \mathrm{m}^{-1}$ provided better grain yields for genotypes UFUS LVR and UFU 7910, respectively. The densities of $12 \mathrm{pl} \mathrm{m}^{-1}$ and $14 \mathrm{pl} \mathrm{m}^{-1}$ allowed a greater number of pods and higher yield for cultivar UFUS 8301 .
\end{abstract}

Additional keywords: yield components; Glycine max (L.) Merrill; plant population.

\begin{abstract}
Resumo
A densidade de semeadura é amplamente estudada na cultura da soja, visando a definir a melhor população de plantas para cada cultivar disponível no mercado. O objetivo do trabalho foi avaliar os caracteres agronômicos de três genótipos de soja (UFUS LVR, UFUS 7910 e UFUS 8301) em quatro densidades populacionais (12; 14; 16; $18 \mathrm{pl} \mathrm{m}^{-1}$ ), em Uberlândia-MG. Utilizou-se delineamento de blocos completos casualizados, com quatro repetições, com semeadura realizada em 12 de fevereiro de 2016. Avaliaram-se altura de plantas na floração (APF) e maturidade (APM); número de nós ramificados (NNR); inclinação dos ramos laterais (IRL); altura da inserção de primeira vagem (AIV); número de vagens por planta (NTV); número de sementes por vagem (NSV); massa de cem grãos (PCG), e produtividade de grãos $\left(\mathrm{kg} \mathrm{ha}^{-1}\right)$. Houve interações significativas entre os genótipos e as densidades para todos os caracteres, exceto para IRL e NSV. Aumentando a densidade de semeadura de 14 para $18 \mathrm{pl} \mathrm{m}^{-1}$, a cultivar UFUS 7.910 apresentou redução na altura de plantas na maturidade, e a linhagem UFU LRV aumentou a altura de inserção da primeira vagem. Não se alterou a massa de cem grãos para as cultivares UFU LRV e UFUS 7.910 com aumento de 12 para $18 \mathrm{pl} \mathrm{m}^{-1}$. Para os três genótipos, houve redução na produtividade de grãos quando semeados com densidade de $18 \mathrm{pl} \mathrm{m}^{-1} \mathrm{em}$ maior densidade de semeadura. As densidades de $16 \mathrm{pl} \mathrm{m}^{-1} \mathrm{e} 12 \mathrm{pl} \mathrm{m}^{-1}$ propiciaram melhores produtividades de grãos para os genótipos UFUS LVR e UFU 7.910, respectivamente. E as densidades de 12 e $14 \mathrm{pl} \mathrm{m}^{-1}$ possibilitaram maiores números de vagens e produtividade para a cultivar UFUS 8.301 .
\end{abstract}

Palavras-chave adicionais: componentes de produção; Glycine max (L.) Merrill; população de plantas. 


\section{Introduction}

Soybean (Glycine max L. Merrill) occupies the largest cultivated area in Brazil (34 million hectares) and is the main legume in the world, with 120 million ha. Among the world's largest producers, Brazil ranks second, contributing with $30 \%$ of the production of the 312 million tons produced in the 2015/2016 harvest (Conab, 2016; USDA, 2016).

The growing increase in crop yield has made the country a world leader in soybean production, as a result of investments in research for the development of new cultivars with high yield potential and tolerant to biotic and abiotic factors, in addition to the development of production technologies.

Crop yield is defined by the interaction between the plant, the production environment, and the management used in the crop. Among the management practices the sowing time, the choice of the cultivar, and the spacing and sowing density are factors that influence the yield and the components of soybean production (Muad et al., 2010).

Sowing density is studied in the soybean crop in order to define the best plant population for each type of cultivar available (Silva et al., 2015). There is no ideal soybean spacing and density for all environments and cultivars, so it is important to observe the interaction between plant spacing and density for each growing condition (Caliskan et al., 2007).

Until the 1980s, it was common to produce soybean with 400,000 plants ha $^{-1}$, or even with higher populations, and yield at that time was around $1900 \mathrm{~kg} \mathrm{ha}^{-1}$. Notwithstanding, the improved precision of seeders and increased quality of seeds produced, along with technological advances, allowed the reduction of the plant population to about 230,000 plants $\mathrm{ha}^{-1}$, and an increase in yield to more than $2500 \mathrm{~kg} \mathrm{ha}^{-1}$ (Embrapa, 2013). Nonetheless, the recommendation of the sowing density depends on the cultivar to be used, the region in which the crop will be planted, the sowing season, and the planting system.

The soybean plant presents a characteristic of high phenotypic plasticity, which consists of the ability to adapt to environmental and management conditions through modifications in morphology and yield components, in order to adapt to the available space and the competitive condition imposed by the plant arrangement (Pires et al., 2000; Rambo et al., 2003).

Morphological changes as a function of sowing density have been reported for soybean cultivation in terms of plant height, number of branches, number of pods per plant, and number of grains per pod (Heiffig, 2002; Komori et al., 2004; Mauad et al., 2010).

Studies performed with sowing densities varying from 15 to 20 plants per meter showed no effect on grain yield (Cortez et al., 2011). This response is related to the phenotypic plasticity that the soybean plants present, since they compensate the reduction of density with an increased individual production of pods, contributing to greater tolerance to this variation. When studying the responses of soybean cultivation under different sowing densities, Cruz et al. (2016) found a negative linear reduction of the total number of pods with a population increase from 7 to 22 plants per linear meter.

Therefore, the use of populations much higher than the recommended ones leads to higher seed costs and can result in crop lodging, not improving grain yield. Moreover, populations below that indicated for the cultivar favor the development of weeds and may result in high losses at harvest (Vasquez et al., 2008).

The ideal plant population should allow high yield, final plant height, and first pod insertion height suitable for mechanized harvesting, in addition to nonlodged plants. In this context, as new soybean cultivars are made available through genetic breeding programs, studies on plant populations are important, since each cultivar will have a specific recommendation depending on the biological cycle, plant height, type of growth, lodging index, and juvenile period.

In view of the above, the objective of this work was to evaluate the influence of sowing density on three soybean genotypes regarding grain yield and morpho-agronomic characters. It is expected that with the change in sowing density, it will be possible to establish the density capable of enabling the maximum expression of the yield potential of the evaluated genotypes.

\section{Materials and methods}

The experiment was carried out in an experimental area of Fazenda Capim Branco (18052' S, $48^{\circ} 20^{\prime} \mathrm{W}$, at an altitude of $805 \mathrm{~m}$ ), belonging to the Federal University of Uberlândia, in the city of Uberlândia, Minas Gerais, in the year 2016.

The meteorological data of the Capim Branco experimental area during the conduction of the experiment are presented in Figure 1, where it can be observed that the rainfall during the experiment period was $308 \mathrm{~mm}$. Considering that rainfall was not sufficient to meet the water demands of the soybean crop, complementary irrigations were carried out.

Three genotypes (UFUS LVR, UFUS 7910, UFUS 8301) were evaluated in four sowing densities $(12 ; 14 ; 16$; 18 plants per meter) in a randomized complete block design with four replicates.

The genotypes of this study were developed by a soybean breeding program, in which UFUS LRV is a strain at final stage of evaluation, and genotypes UFUS 7910 and UFUS 8301 are registered commercial cultivars.

The sowing densities of $12 ; 14 ; 16$; and 18 plants $\mathrm{m}^{-1}$, using a $0.5-\mathrm{m}$ row spacing, correspond, respectively, to the plant populations of 240; 280; 320; and 360,000 plants ha-1 (Embrapa, 2013).

The experimental plot consisted of four soybean planting rows five meters long and spaced $0.5 \mathrm{~m}$ apart. The useful area was formed by the two central 
rows disregarding $0.5 \mathrm{~m}$ at both ends, resulting in four square meters.

The area where the experiment was carried out is located on a Dystrophic Dark Red Latosol. Soil tillage was performed in a conventional manner, with one plowing and two harrowings. Before sowing, the area was furrowed and fertilized, according to
(Table 1), following the recommendations for the use of correctives and fertilizers in Minas Gerais ( $5^{\text {th }}$ version) (Ribeiro et al., 1999). As it is a soil with low natural fertility, it was necessary to apply $450 \mathrm{~kg} \mathrm{ha}^{-1}$ of the formulated 02-28-18 due to the low levels of phosphorus and potassium.

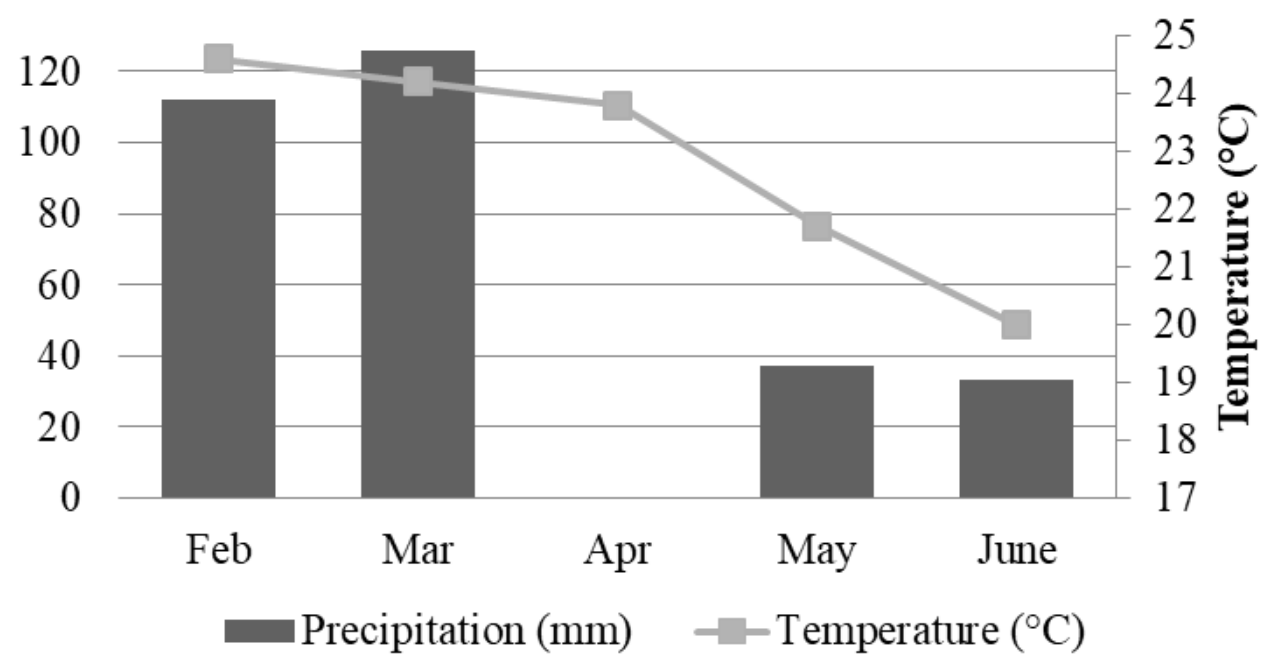

Figure 1 - Average temperature and precipitation in the year 2016, during the months of February to June 2016. Source: Meteorological Station of Fazenda Capim Branco and National Institute of Meteorology (INMET).

Table 1 - Chemical characteristics of the soil, sampled at 0 to $20 \mathrm{~cm}$ depth, in Uberlândia, MG.

\begin{tabular}{|c|c|c|c|c|c|c|c|c|}
\hline \multirow{2}{*}{$\mathrm{pH}\left(\mathrm{H}_{2} \mathrm{O}\right)$} & O.M. & P Mehlich $^{-1}$ & $\mathrm{~K}^{+}$ & $\mathrm{Ca}^{2+}$ & $\mathrm{Mg}^{2+}$ & $\mathrm{Al}^{3+}$ & $\mathrm{H}^{+}+\mathrm{Al}^{+}$ & \multirow{2}{*}{$\begin{array}{l}\mathrm{V} \\
(\%)\end{array}$} \\
\hline & $($ dag kg-1) & $\left(\mathrm{mg} \mathrm{dm}^{-3}\right)$ & \multicolumn{5}{|c|}{----- $\left(\mathrm{cmol}_{\mathrm{c}} \mathrm{dm}^{-3}\right)$ - } & \\
\hline 6.0 & 1.5 & 2.1 & 0.2 & 2.0 & 0.9 & 0.0 & 2.20 & 59 \\
\hline
\end{tabular}

O.M. Organic matter; V: Saturation of bases.

Prior to sowing, a germination test was carried out with the cultivars to determine the number of seeds per meter to reach the desired final density. Manual sowing occurred on February 12, 2016

Also prior to sowing, the seeds were treated with fungicide Carbendazim + Thiram (Protreat $\left.{ }^{\circledR}\right)$, and then inoculated with Bradyrhizobium japonicum containing two strains of the bacterium.

Weed control was performed with herbicide SMetolachlor (Dual Gold ${ }^{\circledR}$ ) after sowing, and Haloxifope-P-Methyl (Verdict $\left.{ }^{\circledR}\right) 30$ days after sowing, supplemented with manual weeding.

At 30 days after emergence, cobalt and molybdenum $\left(\mathrm{Nectar}^{\circledR}\right)$ were applied at $100 \mathrm{~mL} \mathrm{ha}^{-1}$. For the control of Phakopsorapachyrhizifoi, applications with Trifloxistrobin + Prothioconazole $\left(\mathrm{Fox}^{\circledR}\right)$ were performed at $0.4 \mathrm{~L} \mathrm{ha}^{-1}$, and pest control was carried out when necessary with Acefate $\left(\right.$ Achero $\left.^{\circledR}\right)$ at $0.4 \mathrm{~kg} \mathrm{ha}^{-1}$, and Thiamethoxam + Lambda-Cyhalothrin (Platinum $\mathrm{Neo}^{\circledR}$ ), with $200 \mathrm{~mL}^{-1}$.

In the useful plot, five plants were randomly sampled, which were identified with a colored ribbon, and the following characters were measured by means of visual observations and measurements according to the stages of development of the crop, proposed by Fehr \& Caviness (1977):

a) plant height at flowering (PHF): in centimeters $(\mathrm{cm})$, measured from the soil surface to the last node on the main stem, in the R1 stage;

b) plant height at maturity (PHM): in centimeters $(\mathrm{cm})$, measured from the soil surface to the last node on the main stem of the plant, at stage R8;

c) number of nodes in the main stem at maturity (NNMS): at maturity (stage R8), all nodes visible on the main stem;

d) number of branched nodes (NBN): branched nodes were counted visible on the main stem;

e) slope of lateral branches (SLB): measure of the angle between the main stem and the lateral branches, measured with a protractor;

f) first pod insertion height (FPIH): in centimeters $(\mathrm{cm})$, measured from the soil surface to the first pod;

g)100-grain weight (HGW): after a harvest and 
processing of the plants the weight of one hundred grains in precision scale;

h) total number of pods per plant (NPP): after harvest, all pods of five plants randomly sampled were counted and then averaged per plant;

i) number of seeds per pod (NSP): the average number of seeds per pod from randomly collected plants from each useful plot was counted after harvesting;

j) grain yield $\left(\mathrm{kg} \mathrm{ha}^{-1}\right)$ : Accomplished through harvesting, threshing, and weighing the soybean seeds from the useful plot. Data obtained (grams per useful plot) were transformed into $\mathrm{kg} \mathrm{ha}^{-1}$. The weight of each sample was corrected to $13 \%$ humidity.

The data were submitted to analysis of variance in a factorial scheme $(3 \times 4)$, the factors consist- ing of three genotypes and four densities. The interactions among factors, as well as the significant isolated factors were submitted to the Tukey test at 5\% probability, with the aid of the Sisvar program (Ferreira, 2011). Although density is a quantitative factor, it was chosen to treat it as qualitative, since it was not possible to adjust regressions that would explain the biological phenomenon.

\section{Results and discussion}

A significant interaction was observed between genotypes and densities for all traits, except for slope of lateral branches and number of seeds per pod, whose significant effects were observed for the factors alone (Table 2).

Table 2 - Summary of variance analysis for agronomic traits of three soybean cultivars under four sowing densities during the year of 2016 in Uberlândia - MG.

\begin{tabular}{|c|c|c|c|c|c|c|}
\hline \multirow{2}{*}{ Causes of variation } & \multirow{2}{*}{ FD } & \multicolumn{5}{|c|}{ Mean squares } \\
\hline & & PHF & PHM & NNMS & NBN & SLB \\
\hline Genotype (G) & 2 & $3.91^{\mathrm{ns}}$ & $93.95^{*}$ & $6.31^{*}$ & $3.19^{*}$ & $605.09^{*}$ \\
\hline Sowing density (SD) & 3 & $17.94^{\text {ns }}$ & $21.91^{\text {ns }}$ & $9.19^{*}$ & $4.57^{*}$ & $130.39^{*}$ \\
\hline$G \times S D$ & 6 & $39.57^{*}$ & $73.61^{*}$ & $5.79^{*}$ & $1.08^{*}$ & $38.81^{\text {ns }}$ \\
\hline Blocks & 3 & 4.81 & 19.56 & 2.57 & 0.64 & 84.24 \\
\hline Residue & 33 & 8.86 & 20.73 & 1.77 & 0.39 & 23.14 \\
\hline CV (\%) & & 7.63 & 8.96 & 9.71 & 14.58 & 12.46 \\
\hline \multirow{2}{*}{ Causes of variation } & \multirow{2}{*}{ FD } & \multicolumn{5}{|c|}{ Mean squares } \\
\hline & & $\mathrm{FPIH}$ & Yield & HGW & NPP & NSP \\
\hline Genotype (G) & 2 & $5.20^{\text {ns }}$ & $29414.93^{\text {ns }}$ & $21.527^{\star}$ & $340.41^{*}$ & $0.67^{*}$ \\
\hline Sowing density (SD) & 3 & $6.13^{\text {ns }}$ & $598320.90^{*}$ & $0.38^{\mathrm{ns}}$ & $406.05^{*}$ & $0.07^{\star}$ \\
\hline$G \times S D$ & 6 & $6.00^{\star}$ & $92768.94^{*}$ & $0.57^{*}$ & $46.40^{*}$ & $0.03^{\text {ns }}$ \\
\hline Blocks & 3 & 0.96 & 54454.86 & 0.07 & 21.60 & 0.02 \\
\hline Residue & 33 & 1.34 & 22254.36 & 0.23 & 16.25 & 0.02 \\
\hline CV (\%) & & 12.10 & 11.18 & 4.44 & 14.76 & 6.30 \\
\hline
\end{tabular}

*: significant by F test $(\mathrm{p}<0.05)$; FD: freedom degree; CV (\%): coefficient of variation; PHF and PHM: plant height at flowering and at maturity, respectively; NNMS: number of nodes in the main stem at maturity respectively; NBN: number of branched nodes; NPP: total number of pods per plant; NSP: number of seeds per pod; HGW: 100-grain weight; FPIH: first pod insertion height; SLB: Slope of lateral branches.

The coefficient of variation $(\mathrm{CV})$ ranged from $4.44 \%$ (HGW) to $14.58 \%$ (NBN), values considered low, which evidences control of the causes of environmental variation of a systematic order. According to Carvalho et al. (2003), the maximum acceptable coefficient of variation for soybean is $12 \%$ for plant height and $16 \%$ for grain yield. Coefficients below the limits suggested by the authors were found.

Similar results were found by Hahman \& Hossain (2011) who, when studying the effect of plant density on the growth, yield, and production component of two soybean cultivars, showed CV ranging from $2.86 \%$ (HGW) to $8.78 \%$ (NSP). While Cruz et al. (2016) found CV ranging from $3.82 \%$ (HGW) to $10.73 \%(\mathrm{FPIH})$ when evaluating the effect of sowing densities and plant arrangement on soybean yield.

The plant height at flowering is an important agronomic character, considering that there is influence on the final plant height. In Table 3, it was verified that higher PHF occurred in the densities of $12 \mathrm{pl} \mathrm{m}^{-1}$ and $14 \mathrm{pl} \mathrm{m}^{-1}$ for UFUS 7910, while for the other cultivars there was no difference in plant height with increasing density. 
Table 3 - Plant height at flowering of three soybean genotypes cultivated under four sowing densities, Uberlândia - MG, Brazil, 2016.

\begin{tabular}{llllll}
\hline \multirow{2}{*}{ Genotypes } & \multicolumn{4}{c}{ Sowing density } & \multirow{2}{*}{ Mean } \\
\cline { 2 - 5 } & \multicolumn{1}{c}{$12 \mathrm{pl} \mathrm{m}^{-1}$} & $14 \mathrm{pl} \mathrm{m}^{-1}$ & $16 \mathrm{pl} \mathrm{m}^{-1}$ & $18 \mathrm{pl} \mathrm{m}^{-1}$ & \\
\hline UFUS LVR & $37.73 \mathrm{a} \mathrm{A}$ & $37.93 \mathrm{~b} \mathrm{~A}$ & $39.50 \mathrm{a} \mathrm{A}$ & $43.10 \mathrm{a} \mathrm{A}$ & 39.56 \\
UFUS 7910 & $40.73 \mathrm{a} \mathrm{AB}$ & $43.73 \mathrm{a} \mathrm{A}$ & $35.86 \mathrm{a} \mathrm{B}$ & $35.53 \mathrm{~b} \mathrm{~B}$ & 38.96 \\
UFUS 8301 & $37.85 \mathrm{a} \mathrm{A}$ & $40.73 \mathrm{ab} \mathrm{A}$ & $38.55 \mathrm{a} \mathrm{A}$ & $37.20 \mathrm{~b} \mathrm{~A}$ & 38.58 \\
\hline Mean & 38.77 & 40.79 & 37.97 & 38.61 & \\
\hline
\end{tabular}

Means followed by the same letter, lower case in vertical and upper case in horizontal, do not differ among themselves by Tukey test at $5 \%$ probability.

Most commercial Brazilian cultivars are about 50 to $90 \mathrm{~cm}$ high (Sediyama et al., 2016). It was verified in Table 4 that the final height of the genotypes varied from 42.80 to $55.80 \mathrm{~cm}$, being below the recommended in the literature. This can be explained because the sowing of the experiment was performed outside the recommended season for the soybean crop. These results corroborate those obtained by Cunha et al. (2013), who, when evaluating the performance of soybean strains in off-season sowing, verified final plant height ranging from 34.10 to $68.40 \mathrm{~cm}$.

Table 4 - Plant height at maturity of three soybean genotypes cultivated under four sowing densities, Uberlândia MG, Brazil, 2016.

\begin{tabular}{|c|c|c|c|c|c|}
\hline \multirow{2}{*}{ Genotypes } & \multicolumn{4}{|c|}{ Sowing density } & \multirow{2}{*}{ Mean } \\
\hline & $12 \mathrm{pl} \mathrm{m} \mathrm{m}^{-1}$ & $14 \mathrm{pl} \mathrm{m}^{-1}$ & $16 \mathrm{pl} \mathrm{m}^{-1}$ & $18 \mathrm{pl} \mathrm{m}^{-1}$ & \\
\hline UFUS LVR & 50.33 a $A$ & $47.70 \mathrm{~b} \mathrm{~A}$ & 52.20 a $A$ & 55.80 a $A$ & 51.51 \\
\hline UFUS 7910 & 49.06 a $A B$ & $54.00 \mathrm{ab} A$ & 46.68 a $A B$ & $42.80 \mathrm{~b} \mathrm{~B}$ & 48.13 \\
\hline UFUS 8301 & 50.08 a A & 56.13 a $A$ & 54.53 a $A$ & $50.60 \mathrm{ab} A$ & 52.83 \\
\hline Mean & 49.82 & 52.61 & 51.13 & 49.73 & \\
\hline
\end{tabular}

Means followed by the same letter, lower case in vertical and upper case in horizontal, do not differ among themselves by Tukey test at $5 \%$ probability.

There was no change in the final plant height for genotypes UFUS LVR and UFUS 8301. This disagrees with the results obtained by Mauad et al. (2010), who, when evaluating the influence of sowing density on agronomic traits of the soybean crop, observed higher plants at higher densities. Cruz et al. (2016) reported linear increase of the final plant height with increasing sowing density. These authors explained that the increase in density tends to increase the final plant height due to intraspecific competition for light, leading to the etiolation at higher densities.

UFUS 7910 obtained the highest plant height at maturity at the density of $14 \mathrm{pl} \mathrm{m}^{-1}$. Shamsi \& Kobraee (2011) studied the agronomic responses of soybean cultivars submitted to different plant populations and concluded that one of the cultivars analyzed had the highest plant height in the lowest population evaluated, which is approximately $230,000 \mathrm{pl} \mathrm{ha}^{-1}$.

According to Sediyama et al. (2015), the number and type of soybean branches depend on the particularities of the genetic constitution of each cultivar and the space available for the development of the plants. Thus, intraspecific competition of soybean plants for environmental factors can determine the number of branches. Table 5 shows the reduction of the number of branches per plant with increasing density for the three genotypes. Martins et al. (1999) commented that at higher plant densities, there is less availability of photoassimilates for the vegetative growth of the plants in the form of branches, due to the excessive number of plants in the row, which compete for growth factors, mainly light. This situation limits the availability of photosynthesis products necessary for the development of ramifications in the plant, being mainly destined to the growth in height of the main stem.

When studying the agronomic performance of soybean cultivars in different spatial arrangements, Costa (2013) also found a reduction in the number of branches due to the increase in plant density. Like Cox \& Cherney (2011) and Mauad et al. (2010), who observed a linear reduction in the number of branches per plant with increased populations. 
Table 5 - Number of branched nodes of three soybean genotypes cultivated over four sowing densities, Uberlândia - MG, Brazil, 2016.

\begin{tabular}{|c|c|c|c|c|c|}
\hline \multirow{2}{*}{ Genotypes } & \multicolumn{4}{|c|}{ Sowing density } & \multirow{2}{*}{ Mean } \\
\hline & $12 \mathrm{pl} \mathrm{m}^{-1}$ & $14 \mathrm{pl} \mathrm{m}^{-1}$ & $16 \mathrm{pl} \mathrm{m}^{-1}$ & $18 \mathrm{pl} \mathrm{m}^{-1}$ & \\
\hline UFUS LVR & $4.41 \mathrm{a} \mathrm{A}$ & 4.23 a $A$ & 3.80 a $A B$ & $2.70 \mathrm{~b} \mathrm{~B}$ & 3.78 \\
\hline UFUS 7910 & 5.40 a A & 3.93 a A & 4.83 a $A B$ & 4.46 a B & 4.65 \\
\hline UFUS 8301 & 5.48 a $A$ & 3.53 a B & $4.60 \mathrm{a} A \mathrm{~B}$ & $4.00 \mathrm{a} \mathrm{B}$ & 4.40 \\
\hline Mean & 5.10 & 3.90 & 4.41 & 3.27 & \\
\hline
\end{tabular}

Means followed by the same letter, lower case in vertical and upper case in horizontal, do not differ among themselves by Tukey test at $5 \%$ probability.

In soybean, the growth habit is characterized by the inclination of lateral branches in relation to the main stem. Thus, it is considered erect when this inclination is less than $30^{\circ}$; semi-erect, when inclined from $30^{\circ}$ to $60^{\circ}$; and horizontal, when the inclination is greater than $60^{\circ}$ (Sediyama et al., 2009). Notwith- standing, this character is influenced by the sowing density at which the crop was planted.

Cultivar UFUS 7910 showed a greater inclination of the lateral branches, and the populations that provided the highest inclinations were $14 \mathrm{pl} \mathrm{m}^{-1}$ and $16 \mathrm{pl} \mathrm{m}^{-1}$ (Table 6).

Table 6 - Slope of the lateral branches of three soybean genotypes cultivated over four sowing densities, Uberlândia - MG, Brazil, 2016.

\begin{tabular}{|c|c|c|c|c|c|}
\hline \multirow{2}{*}{ Genotypes } & \multicolumn{4}{|c|}{ Sowing density } & \multirow{2}{*}{ Mean } \\
\hline & $12 \mathrm{pl} \mathrm{m}^{-1}$ & $14 \mathrm{pl} \mathrm{m}^{-1}$ & $16 \mathrm{pl} \mathrm{m}^{-1}$ & $18 \mathrm{pl} \mathrm{m}^{-1}$ & \\
\hline UFUS LVR & 30.80 & 40.46 & 36.00 & 31.85 & $34.77 \mathrm{~b}$ \\
\hline UFUS 7910 & 39.06 & 47.33 & 51.93 & 44.53 & $45.71 \mathrm{a}$ \\
\hline UFUS 8301 & 32.90 & 36.26 & 35.00 & 37.33 & $35.37 \mathrm{~b}$ \\
\hline Mean & $34.25 \mathrm{~B}$ & $41.35 \mathrm{~A}$ & $40.97 \mathrm{~A}$ & $37.90 \mathrm{AB}$ & \\
\hline
\end{tabular}

Means followed by the same letter, lower case in vertical and upper case in horizontal, do not differ among themselves by Tukey test at $5 \%$ probability

The first pod insertion determines the height adjustment of the cutting bar of the harvester, aiming to obtain maximum efficiency during this process and avoiding losses at harvest. In order to avoid these losses, the minimum height of the pod should be 10 to $15 \mathrm{~cm}$ (Sediyama et al., 2015).

For genotype UFUS LVR, the increase in sowing density provided higher first pod insertion height. However, for the other cultivars the sowing density did not influence this variable (Table 7).

When evaluating the agronomic traits of the soybean crop submitted to different population densities, in Rio Grande do Sul, Busanello et al. (2013) found higher values of first pod insertion height in densified cultures. Like Cruz et al. (2016) and Mauad et al. (2010), who observed a linear increase in the first pod insertion height as a function of increased sowing density.

Table 7 - Height of first pod insertion of three soybean genotypes cultivated under four sowing densities, Uberlândia - MG, 2016.

\begin{tabular}{|c|c|c|c|c|c|}
\hline \multirow{2}{*}{ Genotypes } & \multicolumn{4}{|c|}{ Sowing density } & \multirow{2}{*}{ Mean } \\
\hline & $12 \mathrm{pl} \mathrm{m}^{-1}$ & $14 \mathrm{pl} \mathrm{m}^{-1}$ & $16 \mathrm{pl} \mathrm{m}^{-1}$ & $18 \mathrm{pl} \mathrm{m}^{-1}$ & \\
\hline UFUS LVR & 8.46 a B & 8.96 a B & 11.90 a $A$ & 11.50 a $A$ & 10.20 \\
\hline UFUS 7910 & 8.52 a A & 10.43 a $A$ & 9.80 b A & 9.10 a A & 9.46 \\
\hline UFUS 8301 & 8.75 a A & 10.36 a $A$ & $8.96 \mathrm{~b} A$ & 8.26 a A & 9.08 \\
\hline Mean & 8.57 & 9.92 & 10.22 & 9.62 & \\
\hline
\end{tabular}

Means followed by the same letter, lower case in vertical and upper case in horizontal, do not differ among themselves by Tukey test at $5 \%$ probability

The yield component mean grain weight is a character influenced by the genetic constitution of the strains and/or cultivars, as well as by environmental factors. In addition, this character is fundamental for soybean genotypes to reach high grain yields, due to positive correlations between grain weight and soybean yield (Rigon et al., 2012). 
The cultivars normally used to produce oil and meal have a mean weight of 12 to $20 \mathrm{~g}$ per 100 seeds (Sediyama et al., 2016). The population increase did not change the hundred-grain weight for genotypes
UFUS LVR and UFUS 7910 (Table 8), corroborating the results obtained by Mauad et al. (2010) and Cruz et al. (2016), who also did not find differences for the hundred-grain weight in the evaluated densities.

Table 8 - A hundred-seed weight of three soybean genotypes grown over four sowing densities, Uberlândia MG, 2016.

\begin{tabular}{lccrrr}
\hline \multirow{2}{*}{ Genotypes } & \multicolumn{4}{c}{ Sowing density } & \multirow{2}{*}{ Mean } \\
\cline { 2 - 5 } & $12 \mathrm{pl} \mathrm{m}^{-1}$ & $14 \mathrm{pl} \mathrm{m}^{-1}$ & $16 \mathrm{pl} \mathrm{m}^{-1}$ & $18 \mathrm{pl} \mathrm{m}^{-1}$ & \\
\hline UFUS LVR & $11.34 \mathrm{a} \mathrm{A}$ & $10.79 \mathrm{~b} \mathrm{~A}$ & $10.91 \mathrm{a} \mathrm{A}$ & $11.02 \mathrm{a} \mathrm{A}$ & 11.01 \\
UFUS 7910 & $9.29 \mathrm{~b} \mathrm{~A}$ & $9.99 \mathrm{~b} \mathrm{~A}$ & $9.74 \mathrm{~b} \mathrm{~A}$ & $9.74 \mathrm{~b} \mathrm{~A}$ & 9.69 \\
UFUS 8301 & $11.97 \mathrm{a} \mathrm{AB}$ & $12.71 \mathrm{a} \mathrm{A}$ & $11.62 \mathrm{a} \mathrm{B}$ & $11.71 \mathrm{a} \mathrm{B}$ & 12.00 \\
\hline Mean & 10.87 & 11.16 & 10.75 & 10.82 & \\
\hline
\end{tabular}

Means followed by the same letter, lower case in vertical and upper case in horizontal, do not differ among themselves by Tukey test at $5 \%$ probability

It was verified that cultivar UFUS 8301 showed the largest hundred-grain weight in the populations of $12 \mathrm{pl} \mathrm{m}^{-1}$ and $14 \mathrm{pl} \mathrm{m}^{-1}$. A possible explanation for this behavior is that at lower sowing densities, there is usually a higher production of pods per plant and a higher number of grains per pods, with no light restriction due to the better plant distribution in the area, with the production of photoassimilates being sufficient for better grain filling (Mauad et al., 2010).

Due to the correlation with grain yield, the total number of pods is one of the most important components of soybean production (Leite et al., 2016; Vianna et al., 2013). According to Câmara (1998), Brazilian cultivars present, on average, from 30 to 80 pods per plant, which can present from 1 to 4 seeds per pod.

It was observed that there was a reduction in the number of pods per plant as a function of increased sowing density in the three genotypes (Table 9). Mauad et al. (2010) explain that at high sowing densities, there is a greater competition for light and a reduced availability of photoassimilates, causing the plant to decrease the number of branches and produce a smaller number of nodes and, consequently, fewer pods.

Table 9 - Total number of pods per plant of three soybean genotypes grown at four sowing densities, Uberlândia MG, Brazil, 2016.

\begin{tabular}{|c|c|c|c|c|c|}
\hline \multirow{2}{*}{ Genotypes } & \multicolumn{4}{|c|}{ Sowing density } & \multirow{2}{*}{ Mean } \\
\hline & $12 \mathrm{pl} \mathrm{m}^{-1}$ & $14 \mathrm{pl} \mathrm{m}^{-1}$ & $16 \mathrm{pl} \mathrm{m}^{-1}$ & $18 \mathrm{pl} \mathrm{m}^{-1}$ & \\
\hline UFUS LVR & 28.65 b A & $26.43 \mathrm{~b}$ AB & $25.20 \mathrm{~b} \mathrm{AB}$ & 19.45 a B & 24.93 \\
\hline UFUS 7910 & $43.20 \mathrm{a} A$ & 33.53 a B & $32.21 \mathrm{a} \mathrm{B}$ & 21.60 a C & 32.63 \\
\hline UFUS 8301 & $31.31 \mathrm{~b} \mathrm{~A}$ & 20.20 b B & $26.51 \mathrm{ab} A B$ & 19.53 a B & 24.38 \\
\hline Mean & 34.38 & 26.72 & 27.97 & 20.19 & \\
\hline
\end{tabular}

Means followed by the same letter, lower case in vertical and upper case in horizontal, do not differ among themselves by Tukey test at $5 \%$ probability

Cruz et al. (2016), evaluating soybean cultivation under different sowing densities and spatial arrangements, observed a negative linear effect of the total number of pods as a function of the increase in sowing density. Similar results were also obtained by Knebelet et al. (2006) and Busanello et al. (2013) in studies of different populations and spacing between plants for the soybean crop.

It was observed that the lowest number of beans per pod was obtained at the density of $18 \mathrm{pl} \mathrm{m}^{-1}$
(Table 10). Ludwig et al. (2011) verified that the number of grains per pod was affected by the plant population, occurring reduction in the number of grains with increased plant population. Likewise, Mauad et al. (2010) verified a negative linear response of the number of grains per pod as a function of the increase in density, evidencing that the total number of grains is related to the total number of pods, and that the reduction in the total number of pods directly affects the number of grains per pod. 
Table 10. Number of grains per pod of three soybean genotypes cultivated under four sowing densities, Uberlândia - MG, Brazil, 2016.

\begin{tabular}{|c|c|c|c|c|c|}
\hline \multirow{2}{*}{ Genotypes } & \multicolumn{4}{|c|}{ Sowing density } & \multirow{2}{*}{ Mean } \\
\hline & $12 \mathrm{pl} \mathrm{m}^{-1}$ & $14 \mathrm{pl} \mathrm{m}^{-1}$ & $16 \mathrm{pl} \mathrm{m}^{-1}$ & $18 \mathrm{pl} \mathrm{m}^{-1}$ & \\
\hline UFUS LVR & 2.30 & 2.33 & 2.20 & 2.22 & $2.26 \mathrm{~b}$ \\
\hline UFUS 7910 & 2.41 & 2.32 & 2.38 & 2.04 & $2.29 \mathrm{~b}$ \\
\hline UFUS 8301 & 2.65 & 2.65 & 2.64 & 2.58 & $2.63 a$ \\
\hline Mean & $2.45 \mathrm{~A}$ & $2.43 \mathrm{AB}$ & $2.40 \mathrm{AB}$ & $2.28 \mathrm{~B}$ & \\
\hline
\end{tabular}

Means followed by the same letter, lower case in vertical and upper case in horizontal, do not differ among themselves by Tukey test at $5 \%$ probability

The yield potential of a genotype depends on its genetic constitution, as well as on cultivation conditions, such as the sowing time, the spacing and sowing density used in crop establishment, and water and nutrient availability. In this context, the ideal plant population of each genotype should be determined from specific studies for this purpose.

In this work, a large amplitude was observed in grain yield means, from 1364.51 to $2350.25 \mathrm{~kg} \mathrm{ha}^{-1}$ (Table 11), which were below the mean yield in the state. This behavior is explained by the fact that the sowing of the experiment was carried out late, that is, after the time recommended for the soybean crop in the state of Minas Gerais (Silva et al., 2015). Similar results were found by Cunha et al. (2013) in late sowing of 79 soybean progenies from the Genetic Breeding Program of the Federal University of Uberlândia.

There was a reduction in grain yield with increasing sowing density (Table 11). The results corroborate those of Hahman \& Hossain (2011), who evaluated the effect of plant density on the growth, yield, and production component of two soybean cultivars. This is explained by the fact that some cultivars can better express the yield potential of each plant to the point of exceeding the largest number of plants in the row.

Table 11 - Yield $\left(\mathrm{kg} \mathrm{ha}^{-1}\right)$, evaluated of three soybean genotypes cultivated under four sowing densities, Uberlândia - MG, Brazil, in 2016.

\begin{tabular}{llllll}
\hline \multirow{2}{*}{ Genotypes } & \multicolumn{4}{c}{ Sowing density } & \multirow{2}{*}{ Mean } \\
\cline { 2 - 5 } & \multicolumn{1}{c}{$12 \mathrm{pl} \mathrm{m}^{-1}$} & $14 \mathrm{pl} \mathrm{m}^{-1}$ & $16 \mathrm{pl} \mathrm{m}^{-1}$ & $18 \mathrm{pl} \mathrm{m}^{-1}$ & \\
\hline UFUS LVR & $2016.18 \mathrm{~b} \mathrm{~A}$ & $1912.20 \mathrm{a} \mathrm{A}$ & $2080.48 \mathrm{a} \mathrm{A}$ & $1364.51 \mathrm{a} \mathrm{B}$ & 1843.34 \\
UFUS 7910 & $2410.11 \mathrm{a} \mathrm{A}$ & $1704.63 \mathrm{a} \mathrm{B}$ & $1718.04 \mathrm{~b} \mathrm{~B}$ & $1461.71 \mathrm{a} \mathrm{B}$ & 1823.62 \\
UFUS 8301 & $2350.25 \mathrm{ab} \mathrm{A}$ & $2058.57 \mathrm{a} \mathrm{AB}$ & $1673.67 \mathrm{~b} \mathrm{~B}$ & $1663.14 \mathrm{a} \mathrm{B}$ & 1936.41 \\
\hline Mean & 2258.85 & 1891.80 & 1824.06 & 1496.49 & \\
\hline
\end{tabular}

Means followed by the same letter, lower case in vertical and upper case in horizontal, do not differ among themselves by Tukey test at $5 \%$ probability

In contrast, Busenello et al. (2013), Ludwig et al. (2011), Sousa et al. (2010), and Freitas et al. (2010) found that increasing sowing density did not provide an increase in yields for the soybean crop. While Cruz et al. (2016) observed increases in grain yield as the plant population increased.

In view of the results presented, genotype UFUS LVR expressed better its yield potential with a population between 12 and $16 \mathrm{pl} \mathrm{m}^{-1}$, although the sowing was performed outside the recommended period. UFUS 7910 has its highest yield performance in the population of $12 \mathrm{pl} \mathrm{m}^{-1}$. And it is recommended that UFUS 8301, when sown late, should be conducted with a population between 12 and $14 \mathrm{pl} \mathrm{m}^{-1}$.

\section{Conclusions}

In late sowing, the agronomic traits and yield components were influenced differently between genotypes and sowing density.

The density of $16 \mathrm{pl} \mathrm{m}^{-1}$ favored the agronomic traits and a higher grain yield for genotype UFUS LVR.

Cultivar UFUS 7910 showed favorable agronomic traits and better grain yield at the sowing density of $12 \mathrm{pl} \mathrm{m}^{-1}$.

Cultivar UFUS 8301 showed a higher number of pods and a higher yield at 12 and $14 \mathrm{pl} \mathrm{m}^{-1}$.

\section{Acknowledgements}

To the Foundation for Research Support of the State of Minas Gerais (FAPEMIG) and the Coordination for the Improvement of Higher Education Personnel (CAPES), for the financial support.

\section{References}

Busanello CR, Somavilla L, Menengol DR (2013) Caracteres agronômicos da cultura da soja submetida a diferentes densidades populacionais na região norte do Rio Grande do Sul. Enciclopédia Biosfera 9(17):509-517. 
Caliskan S, Arslan M, Uremis I, Caliskan ME (2007) The effects of row spacing on yield and yield components of full season and double-cropped soybean. Turkish Journal of Agriculture and Forestry 31(3):147-154 .

Câmara GMS (1998) Soja: tecnologia de produção. Piracicaba: ESALQ/USP. 293p.

Carvalho CGP, Arias CAA, Toledo JFF, Almeida LA, Hiihl RAS, Oliveira FO, Hiromoto DM, Takeda C (2003) Proposta de classificação dos coeficientes de variação em relação à produtividade e altura da planta de soja. Pesquisa Agropecuária Brasileira 38 (2):187-193.

Conab - Companhia Nacional de Abastecimento (2016) Acompanhamento da safra brasileira: grãos: primeiro levantamento, outubro, 2016. Brasília: Conab, 2016. Disponível em:http://www.conab.gov.br (Acesso em 1 out. 2016).

Cortez JW, Furlani CEA, Silva RP, Román RAA. (2011) Características agronómicas de la soya en función de las densidades de siembra y profundidad de deposición de abono. Revista Ceres 58(1):62-68.

Costa ED (2013) Arranjo de plantas, características agronômicas e produtividade de soja. UNESP (Dissertação de mestrado em Agronomia).

Cox WJ, Cherney JH (2011) Growth and yield responses of soybean to row spacing and seeding rate. Agronomy Journal 103(1):123-128.

Cruz SCS, Sena Junior DG, Santos DMA, Lunezzo LO, Machado CG (2016) Cultivo de soja sob diferentes densidades de semeadura e arranjos espaciais. Revista de Agricultura Neotropical 3(1):1-6.

Cunha MCG,Hamawaki OT, Sousa LB (2013) Genetic variability among 79 soybean progênies from UFU breeding program. Bioscience Jornal 29(2):340-349.

Embrapa - Empresa Brasileira de Pesquisa Agropecuária (2013) Tecnologias de produção de soja: região central do brasil. Embrapa soja. 266p.

Fehr WR, Caviness CE (1977) Stage of soybean development. Ames: lowa State University of Science and Technology.11p.

Ferreira DF (2011) Sisvar: a computerstatisticalanalysis system. Ciência e Agrotecnologia 35(6):1039-1042.

Freitas MCM, Hamawaki OT, Bueno MR, Marques MC (2010) Época de semeadura e densidade populacional de linhagens de soja UFU de ciclo semitardio. Bioscience Journal 26(5):698-708.

Hahman MM, Hossain MM (2011) Plant density effects on growth, yield and yield components of two soybean varieties under equisistant planting arrangement. Asian Journal of Plant Sciences 10(5):278-286.
Heiffig SL (2002) Plasticidade da cultura da soja (Glycine max (L.) Merrill) em diferentes arranjos espaciais. ESALQ/USP (Dissertação de mestrado em Agronomia).

Knebel JL, Guimaraes VF, Andreotti M, Stangarlin JR (2006) Influência do espaçamento e população de plantas sobre doenças de final de ciclo e oídio e caracteres agronômicos em soja. Acta Scientiarum. Agronomy 28(3):385-392.

Komori E, Hamawaki OT, Souza MP, Shigihara D, Batista AM (2004) Influência da época de semeadura e população de plantas sobre características agronômicas na cultura da soja. Bioscience Jornal 20(3):13$-19$.

Leite WS, Pavan BE, Matos Filho CHA, Alcantra Neto F, Oliveira CB, Feitosa FS (2016) Estimativas de parâmetros genéticos, correlações e índices de seleção para seis caracteres agronômicos em linhagens F8 de soja. Comunicata Scientiae 7(3):302-310.

Ludwig MP, Dutra LMC, Lucca Filho OA, Zabot L, Jauer A, Uhry D (2011) Populações de plantas na cultura da soja em cultivares convencionais e roundupread. Revista Ceres 58(3):305-313.

Martins MC, Câmara GMS, Peixoto CP, Marchiori LFS, Leonardo V, Mattiazzi P (1999) Épocas de semeadura, densidades de plantas e desempenho vegetativo de cultivares de soja. Scientia Agricola 56(4):851-858.

Mauad M, Silva TLB, Almeida Neto AL, Abreu VG (2010) Influência da densidade de semeadura sobre características agronômicas na cultura da soja. Revista Agrarian 3(9):175-181.

Pires JFL, Costa JA, Thomas AL, Maehler AR (2000) Efeito de populações e espaçamentos sobre o potencial de rendimento da soja durante a ontogenia. Pesquisa Agropecuária Brasileira 35(8):1541-1547.

Pires JLF,Costa JA, Thomas AL (1998) Rendimento de grãos de soja influenciado pelo arranjo de plantas e níveis de adubação. Pesquisa Agropecuária Gaúcha $4(2): 183-188$.

Rambo L, Costa JA, Pires JLF, Parcianello G, Ferreira FG (2003) Rendimento de grãos da soja em função do arranjo de plantas. Ciência Rural 33:405-411.

Ribeiro AC, Guimarães PTG, Alvarez VVH Recomendações para 0 uso de corretivos e fertilizantes em Minas Gerais. Viçosa, MG: Comissão de Fertilidade do Solo do Estado de Minas Gerais CFSEMG, 1999. 359p.

Rigon JPG, Capuanil S, Netoll JFB, Rosa GM, Wastowski AD, Rigon CAG (2012) Dissimilaridade genética e análise de trilha de cultivares de soja avaliada por meio de descritores quantitativos. Revista Ceres 59(2): 233-240. 
Sediyama T, Silva F, Borém A (2015) Soja: do plantio à colheita. UFV. 333p.

Sediyama T, Teixeira RC, Barros HB (2009) Origem, evolução e importância econômica. In: Sediyama T (ed.) Tecnologias de produção e usos da soja, Mecenas. p. 1-5.

Sediyma T, Oliveira RCT, Sediyama HAA (2016) Soja. In: Sediyama T (ed.) Produtividade da soja, Mecenas. p. 11-18.

Shamsi K, Kobraee S (2011) Soybean agronomic responses to plant density. Annals of Biological Research 2(4):168-17.

Silva AF, Sediyama T, Borém A, Silva FCS (2015) Cultivares. In: Sediyama T, Silva F, Borém A (eds). Soja do plantio à colheita, UFV. p. 9-167.

Silva FL, Soares MM, Silva FA, Sediyama T, Borém A (2015) Época de semeadura e densidade de plantas. In: Sediyama T, Silva F, Borém A (eds). Soja do plantio à colheita, UFV. p. 149-167.
Sousa CA, Gava F, Casa RT, Bolzan JM, Kuhnem Junior PR (2010) Relação entre densidade de plantas e genótipos de soja roundupready. Planta Daninha 28 (4):887-896.

USDA - United States Department Of Agriculture (2016) Oilseeds: World Markets and Trade. Foreign Agricultural Service/USDA - Office of Global Analysis. p. 1-37.

Vasquez GH, Carvalho NM, Borba MMZ (2008) Redução na população de plantas sobre a produtividade e qualidade fisiológica da semente de soja. Revista Brasileira Sementes 30(2):1-11.

Vianna VF, Uneda-Trevisoli SH, Desiderio JA, Santiago S, Charnai K, Ferreira Junior JA, Ferraudo AS, Di Mauro O (2013) The multivariate approach and influence of characters in selecting superior soybean genotypes. African Jornal of Agricultural Research 8(30):4162-4169. 